\title{
Analysis of Education Financing Management (Multi Case in SMPN 1 and SMPN 3 Pringgabaya)
}

\author{
Dading Murni Anggraini \\ University of Mataram
}

http://dx.doi.org/10.18415/ijmmu.v5i6.923

\begin{abstract}
The purpose of this study was to describe the management of education funding at SMPN 1 and SMPN 3 Pringgabaya, starting from the planning stage, the implementation phase, to the evaluation phase of education funding. The approach used in this study was a qualitative approach with the type of multicase location at SMPN 1 and SMPN 3 Pringgabaya. Sources of data in this study are informants, documents, and physical devices. Data collection techniques using interview, observation, and documentation techniques. Data analysis techniques using data reduction, data presentation, and data verification. Check the validity of the data by triangulation which includes triangulation of sources and methods. The results of data analysis show that 1) the planning phase of education funding at SMPN 1 and SMPN 3 Pringgabaya is carried out through a continuous meeting mechanism. Meeting.This is carried out at the beginning of each year attended by principals, treasurers, teacher boards, and school committees. This meeting aims to form a drafting team of RKAS and determine the amount of allocation for each type of expenditure. Furthermore, the RKAS drafting team identified the source of the school revenue budget, identified the school budget plan, consulted the RKAS with the school committee. Furthermore, the RKAS was ratified and signed by the Principal, Treasurer and Committee, and also requested approval from the Head of the East Lombok District National Education Office, which was the BOS Management Team. The design of the RKAS refers to the technical instructions for using BOS funds. 2) the implementation phase of funding, SMPN 1 and SMPN 3 Pringgabaya refer to the RKAS that has been approved by the principal and the school committee. Flow of entry and exit of funds is handled by the treasurer who has been appointed by the principal starting from withdrawing funds and carrying out bookkeeping related to transactions financed using BOS funds. 3) the evaluation phase of education funding at SMPN 1 and SMPN 3 Pringgabaya is carried out by internal and external parties. Internal evaluation of school finance is carried out by the principal through an examination of the monthly financial statements and assets and facilities owned by the school. By looking at the report the principal will find out how much income is earned and expenditure spent in one month. External evaluations are carried out by the school committee and the government. School committees can check school finances through general cash books or financial reports that have been made by the school. Every quarter the school sends a report format for the use of online boss funds to the East Lombok district education office to be examined and at the end of each school year it is required to account for any funds spent during a budget year to be thoroughly examined at any time.
\end{abstract}

Keywords: Management of Education Financing; SMPN 1; SMPN 3 Pringgabaya 


\section{Introduction}

Education has an important role in improving the quality of human resources. This is because education will affect productivity community where it is closely related to the overall process of structuring and using resources to achieve educational goals effectively and efficiently. Education makes human resources more able to understand and be ready to face changes in the work environment (Fattah, 2012). Education is said to be successful if it can create humans who have good cognitive, affective, and psychomotor abilities. These abilities are reflected in the reality of life which shows the extent to which the quality of the individual as a result of the education he obtained.

Schools that are educational institutions have a very large role as agents of change, as well as to prepare students through guidance, teaching and training activities, so that they are ready to enter a globally competitive era. The government must be serious in handling the field of education because with good education it is expected that the next generation of quality, superior and competitive emerges. To realize a quality education, it is necessary to have a comprehensive and professional management of the resources available at educational institutions including the management of financing as the heart of the course of education.

The cost of education has a very important role, almost no educational effort can ignore the role of costs, so that it can be said that without costs, the education process (in school) will not work (Supriadi, 2004). The policy on financing in Indonesia is stated in the Act No. 20 of 2003 concerning Article 49 paragraph (1) of the National Education System which states that education funds other than educators' salaries and official education fees are allocated at least $20 \%$ of the State Budget (APBN) in the education sector and at least $20 \%$ of the Revenue and Expenditure Budget Regional (APBD). One of them is by channeling School Operational Assistance (BOS) funds.

In line with the regional autonomy policy which issues education issues to their respective regions and schools, the problem is finance is also the authority given directly to the management of the school. So that the financing component needs to be managed as well as possible, so that existing funds can be utilized optimally to support the achievement of educational goals. And principals have full responsibility for planning, implementing, and evaluating school finances (Mulyasa, 2006). Therefore, principals must look carefully at their role as administrators in empowering all available funding sources, for the sake of the school and achieving school goals as expected by all stakeholders.

Various sources of funds owned by a school, both from the government and other parties. When public funds or other third party funds flow in, a professional and honest financial management system must be prepared. The activity of allocating funds in the implementation of operational education is a very complex activity, therefore it requires planned management by competent people. If this is not fulfilled, it will cause problems that can hinder the implementation of education. Some of the problems that often occur in education funding include limited funding sources, uneven education funds received from the government, lack of transparency in the financing of education in schools, and funding that is not managed well which can be caused by lack of competent fund managers in schools.

Government Regulation No. 17 of 2010 Articles 50 and 51 concerning management and implementation of education clearly state that the obligation of the education unit to formulate and stipulate education policies in accordance with their authority. One of the education policies formulated is the education unit namely the School Activity and Budget Plan (RKAS). In an educational calendar year, the RKAS must reflect all school needs, be able to function properly for the school itself as a work guideline or framework in school development, as well as a reference in identifying the educational resources that are needed in school development, as well as functioning for the government as an evaluation tool for school development. 


\section{Research Methods}

This study has used a qualitative approach, namely observing periodically the visible phenomena, situations and conditions of the object of research whose information can be taken from various respondents and other supporting documents.

The type of research is classified as multi-case research, because the objects to be studied are two schools, namely SMPN 1 and SMPN 3 Pringgabaya.

The data in this study are divided into two forms, namely primary and secondary data. Primary data will be obtained through observation and interviews with informants at SMPN 1 and SMPN 3 Pringgabaya covering management of education funding and other supporting data that have an impact on student activities in improving the teaching and learning process in the school. While secondary data are documents, photographs and objects that can be used as a complement to the primary data relating to the management of education funding in the school.

The data sources in this study are divided into three, namely:

\begin{tabular}{lll}
\hline Informant & Document & $\begin{array}{l}\text { Physical } \\
\text { Devices }\end{array}$ \\
\hline Headmaster & School Work Plan & Room \\
School & and Budget & Soil Main \\
Committee & (RKAS ) & Book \\
Treasurer & Plan for Use of & Equipment \\
Teacher & Funds ( IDR D) & Meublier \\
& General Cash & \\
& Book & \\
& Cash Ledgers & \\
& Bank Ledgers & \\
& Tax Assistant & \\
& Book & \\
& Ledgers Details of & \\
& Shopping Objects & \\
& Report on & \\
& Realization of & \\
& BOS Funds & \\
& List of Month & \\
& Reports &
\end{tabular}

Data collection techniques using interview, observation, and documentation techniques. Data analysis techniques using data reduction, data presentation, and data verification. Check the validity of the data by triangulation which includes triangulation of sources and methods. The main instrument in this study is the researchers themselves. The supporting instruments are used to assist researchers as the main instruments, namely interview guidelines, document analysis rubrics, and observation instruments for infrastructure. 


\section{Discussion}

\section{Analysis of Education Financing Planning Phase}

RKAS preparation for schools is something that must be planned in the financing budgeting process. Likewise with SMPN 1 and SMPN 3 Pringgabaya in compiling the RKAS, they implemented it through a number of stages, namely starting with holding school meetings, identifying the sources of school revenue budgets, identifying plans for school expenditures, consulting RKAS with school committees, and ratifying RKAS. In the preparation of the budget involves the principal, treasurer, school committee, teacher council, and administration. This is in line with Fattah (2012) that basically budgeting is a negotiation or negotiation as well as an agreement between the leader and his subordinates in determining the amount of the budget allocation for a budget.

RKAS compilation carried out by SMPN 1 and SMP 3 Pringgabaya systematically to achieve a truly efficient budget for improving the quality of education. Fattah (2012) suggests that in the budgeting process is how to use funds efficiently, allocate them appropriately, according to priority scale and through systematic procedures. In the RKAS of SMPN 1 Pringgabaya it was noted that the amount of BOS funds for school program activities was Rp. 1,124,200,000.00. This amount is budgeted for one year in improving the quality of education through school programs. Whereas Pringgabaya 3 Junior High School recorded the amount of BOS funds received which was Rp. 726,000,000.00. With such budgeting, the two schools have been able to provide relatively affordable education for rural communities who are generally in middle to lower economic conditions with the title of favorite school in the Pringgabaya subdistrict.

\section{Analysis of the Phase of Education Financing Implementation}

The implementation of funding for education at SMPN 1 and SMPN 3 Pringgabaya is in accordance with the RKAS that has been prepared. There is a difference in the administration or recording of financing which is an important step in implementing financial transparency in education. in the bookkeeping of BOS funds, what must be done is a general cash book, cash assistant book, tax ledger, and bank ledger. The bookkeeping format in these books is quite simple. The recommended workmanship is that every transaction occurs immediately booked, this will make it easier so that the evidence is not lost or exchanged and the financial position is always updated quickly. Besides the existence of these books, the important thing that must be done is to store the transaction evidence. Proof of transaction must be stored and compiled in accordance with the provisions.

Pringgabaya SMPN 1 conducts complete financial records such as using several financial records, such as General Cash Book, Cash Assistance Book, Bank Ledgers, and Tax Ledgers, Ledgers for Object Shopping Details, BOS Fund Realization Reports, Month Report Lists and supporting documents evidence of BOS expenditure. These financial records have met the principle of accountability where each record can be accounted for in accordance with a predetermined plan. The financial records conducted at Pringgabaya 1 Public Middle School have been able to explain the existing finances. By utilizing the functions of each financial record it is easier for the principal to conduct financial analysis of his school and to make transparent financial reports to improve the quality of education.

While Junior High School 3 Pringgabaya records using financial records such as the General Cash Book and there are still some bookkeeping functions that have not been implemented at Pringgabaya 3 Public Middle Schools such as Cash Assistants, Bank Ledgers, Tax Assistants Books. According to Indra (2006) Bookkeeping is also important because every accounting that is done has its own accounting function in the school financial process. 


\section{Analysis of Educational Financing Evaluation Phase}

Evaluate education funding that aims to ensure that budgeted funds are actually used according to school policy rules and procedures. Every quarter, schools receiving BOS funds are required to report on the use of BOS funds. BOS funds have the formats specified in the management manual. For BOS funds, reports that must be given to the District BOS Management Team are RKAS, Quarter I-IV RPD, General Cash Books, Cash Assistance Books, Bank Ledgers, and Tax Ledgers, as well as supporting documents for proof of BOS funds. In addition to the evidence of the expenditure, the school also attached an accountability report on the activities in which the BOS funds were used. All formats and recalcitrant SPJ will be examined by a special verification team that will examine all the completeness of the accountability. If there is an error, the report will be returned to the school to be repaired.

Pringgabaya 1 Public Middle School evaluates funding through internal parties carried out by the principal and external parties carried out by the school committee and the community as well as the government which in this case is the education office of the East Lombok Regency Evaluation is done by checking each report finance regarding revenue and expenditure. This is in agreement with Fattah (2012) that budget checks are basically activities to assess, record and procedure in implementing the budget in accordance with applicable regulations. This funding evaluation should use procedures and records of financial results even though every month the school treasurer reports it to the school. The inspection record is very useful as proof of financial transparency carried out by Pringgabaya 1 Public Middle School. During monitoring to schools, other books besides RKAS were also complete. The results of the process can be accessed easily because it is stored on the treasurer and recalcitrant SPJ computers also stored properly. Unlike the Pringgabaya 3 Public Junior High School, during the evaluation phase there were no serious errors found related to usage, only the administrative requirements still had to be completed.

\section{Conclusion}

Based on the results of research conducted by researchers at SMPN 1 and SMPN 3 Pringgabaya about the management of education funding, the following conclusions can be drawn:

1. The education financing planning stage at SMPN 1 and SMPN 3 Pringgabaya is carried out through a continuous meeting mechanism. Meeting This is carried out at the beginning of each year attended by principals, treasurers, teacher boards, and school committees. This meeting aims to form a drafting team for RKAS and determine the amount of allocation for each type of expenditure. Furthermore, the RKAS drafting team identified the source of the school revenue budget, identified the school budget plan, consulted the RKAS with the school committee. Furthermore, the RKAS was ratified and signed by the Principal, Treasurer and Committee, and also requested approval from the Head of the East Lombok District National Education Office, which was the BOS Management Team. The design of the RKAS refers to the technical instructions for using BOS funds.

2. The implementation phase of funding, SMPN 1 and SMPN 3 Pringgabaya refers to the RKAS that has been approved by the principal and school Committee. The flow of funds outflows is handled by the treasurer who has been appointed by the principal starting from the withdrawal of funds and carrying out bookkeeping related to transactions financed using BOS funds.

3. The evaluation phase of education funding at SMPN 1 and SMPN 3 Pringgabaya is carried out by internal and external parties. Internal evaluation of school finance is carried out by headmaster through examining the monthly financial statements and assets and facilities owned by the school. By looking at the report the principal will find out how much income is earned and expenditure 
spent in one month. External evaluations are carried out by the school committee and the government. School committees can check school finances through general cash books or financial reports that have been made by the school. Every quarter the school sends a report format for the use of online boss funds to the East Lombok district education office to be examined and at the end of each school year it is required to account for any funds spent during a budget year to be thoroughly examined at any time.

\section{References}

Arifin. (2003). Memahami Paradigma Baru Pendidikan Nasional dalam Undang-Undang Sisdiknas: Catatan Ketiga. Jakarta: Ditjen Kelembagaan Agama Islam.

Arikunto, S. (1998). Pengelolaan Kelas dan Siswa. Jakarta: Rajawali Pers.

Arikunto, S. (2009). Manajemen Pendidikan. Yogyakarta: Aditya Media.

Athoillah, A. (2010). Dasar-Dasar Manajemen. Bandung: Pustaka Setia.

Azhari, U.L dan D.A Kurniady. (2016). Manajemen Pembiayaan Pendidikan, Fasilitas Pembelajaran, dan Mutu Sekolah. Jurnal Administrasi Pendidikan, XXIII (2), hal 26-36. Dari https://media.neliti.com/media/publications/77739-ID-manajemen-pembiayaan-pendidikanfasilita.pdf.

Crewell, J.W. (2009). Research Design: Qualitative, Quantitative, and Mixed Methods Approaches, Third Edition. Sage, Los Angeles. Dari https://www.slideshare.net/hennyhyeonhwangi/creswell-johnwresearch-design-qualitative-quantitative-and-mixed.

Fattah, N. (2012). Ekonomi dan Pembiayaan Pendidikan. Bandung: PT. Remaja Rosda Karya.

Handoko, T. H. (2001). Manajemen. Yogyakarta: BPKE Yogyakarta.

Harsono. (2007). Pengelolaan Pembiayaan Pendidikan. Yogyakarta: Pustaka Book Publisher.

Haynes, H. H, Jr. (1992). Planning, Programming and Budgeting System (PPBS): Budget Review and Congressional Action. Thesis. Naval Postgarduate School, Monterey, California.Dari https://apps.dtic.mil/dtic/tr/fulltext/u2/a256136.pdf.

Indra, B. (2006). Akuntansi Pendidikan. Jogjakarta: Erlangga.

Mardiasmo. (2009). Akuntansi Sektor Publik. Edisi Keempat. Yogyakarta: Penerbit ANDI.

Margareta, R.T.E dan B. Ismanto. (2017). Strategi Perencanaan Pembiayaan Sekolah dalam Peningkatan Mutu di SMP Negeri. Jurnal Manajemen Pendidikan KELOLA, 4 (2), hal 195-204. Dari http://ejournal.uksw.edu/kelola/article/view/1123/713.

Matin. (2014). Manajemen Pembiayaan Pendidikan: Konsep dan Aplikasinya. Depok: PT. Rajagrafindo Persada.

Minarti, S. (2011). Manajemen Sekolah: Mengelola Lembaga Pendidikan Secara Mandiri. Jogjakarta: Ar-Ruzz Media. 
Moleong, Lexy J. 2012. Metodologi Penelitian Kualitatif. Bandung: Remaja Rosdakarya.

Mulyasa. (2006). Menjadi Kepala Sekolah Profesional. Bandung: PT Remaja Rosda Karya.

Nafisah, D, Widiyanto, dan W. Sakitri. (2017). Manajemen Pembiayaan Pendidikan di Sekolah Aliyah. Economic Education Analysis Journal, 6 (3), hal 788-797. Dari https://journal.unnes.ac.id/sju/index.php/eeaj/article/view/20316.

Rivenbark, W dan J.M Kelly. (2006). Performance Budgeting in Municapal Governmen. Public Performance and Management Review, 30 (1), hal 35-46. Darihttps://www.researchgate.net/publication/247886930_Performance_Budgeting_in_Municipal _Government.

Suharsaputra, U. (2013). Administrasi Pendidikan. Bandung: PT. Refika Aditama.

Supriadi, D. (2004). Satuan Biaya Pendidikan Dasar dan Menengah. Bandung: PT Remaja Rosda Karya.

Suryabrata, S. (1998). Metodologi Penelitian. Jakarta: Raja Grafindo Persada.

Suwandi dan Soewito. (2015). Financial Management In Public and Private Junior High Schools. The 3rd International Multidiciplinary Conference on Social Sciences. Lecturer of Business Administration, Faculty of Social And Political Sciences, Bandar Lampung University, IV, hal 41-46. Dari http://artikel.ubl.ac.id/index.php/IMCoSS/article/viewFile/408/414.

Tarmizi, Jamaluddin I, dan Djailani AR. (2015). Pengelolaan Pembiayaan Pendidikan melalui Bantuan Operasional Sekolah pada MIN Cempala Kuneng Kabupaten Pidie. Jurnal Administrasi Pendidikan, 3 (4), hal 92-101. Dari http://www.jurnal.unsyiah.ac.id/JAP/article/view/2595.

Ulfatin, N. (2017). Metode Penelitian Kualitatif Di Bidang Pendidikan: Teori dan Aplikasinya. Malang: Media Nusa Creative.

\section{Copyrights}

Copyright for this article is retained by the author(s), with first publication rights granted to the journal.

This is an open-access article distributed under the terms and conditions of the Creative Commons Attribution license (http://creativecommons.org/licenses/by/4.0/). 